\title{
Oppositional Religious Speech: Understanding Hate Preaching
}

\author{
PETER W EDGE \\ Professor of Law, Oxford Brookes University
}

Hate preaching is capable of constituting both hate crime and hate speech, lies at the centre of many religions' understanding of the manifestation of their religion, and frequently raises the contentious issue of regulation of the use of sacred scriptures. This brief article explores the regulation of hate preaching by criminal law, discussing the particular problems posed by oppositional religious speech, before concluding with suggestions for a number of ways to reduce these problems.

Keywords: hate speech, hate crime, preaching, scriptures, law and religion

\section{INTRODUCTION}

In February 2017 two Christians were convicted of a religiously aggravated public order offence - a hate crime - for street preaching. ${ }^{1}$ The prosecutor emphasised that the defendants had quoted from the King James Bible: 'although the words preached are included in a version of the Bible in 1611, this does not mean that they are incapable of amounting to a public order offence in $2016{ }^{\prime 2}$ In a two-day hearing before Bristol Crown Court, the convictions were quashed, on the basis that the defendants had not been hostile towards another religious group, but had been doing no more than expressing their sincerely held religious beliefs. ${ }^{3}$ Cases such as theirs reveal the complexity of hate preaching. Hate preaching is capable of constituting both hate crime and hate speech, ${ }^{4}$ lies at the centre of many religions' understanding of the manifestation of their religion, and frequently raises the contentious issue of regulation of the use of sacred scriptures.

1 An earlier draft of this article was made available to the defence team between the conviction and the appeal.

2 Cited by Christian Concern, 'Street preachers who quoted Bible convicted in "modern-day heresy trial”', 28 February, 2017, available at <http://christianconcern.com/our-concerns/freedom-ofspeech/street-preachers-who-quoted-bible-convicted-in-modern-day-heresy-trial $>, \quad$ accessed 2 March 2018.

3 Overd and Stockwell, Bristol Crown Court (29 June 2017). The judgment of Picton J is not reported, and the transcript of the hearing is not in the public domain, but the appeal is discussed in the Bristol Post, 29 June 2017.

4 See further P Iganski, A Sweiry and J Culpeper, 'A question of faith? Prosecuting religiously aggravated offences in England and Wales', (2016) Crim LR 334-348. 
This article will explore the regulation of hate preaching by criminal law, with a particular focus on hate law. ${ }^{5}$ It begins with an introduction to oppositional religious speech and the possibility of such speech being hateful. This is followed by a brief discussion of hate law, with a focus on hate speech and hate crime which can be committed by speech. The article then shows the particular problems posed by the regulation of oppositional religious speech as hate speech, before concluding with a consideration of ways forward.

\section{OPPOSITIONAL RELIGIOUS SPEECH}

One important definition of religion requires a belief system that 'teach[es] its adherents how they are to live their lives'. 6 This emphasis on a code of conduct is sometimes used to distinguish religion and race. ${ }^{7}$ A code of conduct may fit neatly with state values at any given time. Of much more significance are the occasions when the religious values clash with state values.

Consideration of this sort of clash tends to focus on the benefits of expression to the speaker, the costs to the speaker of restricting their expression, and the costs to targets of such expressions and others. ${ }^{8}$ The recent Law Commission report on hate crime rarely discusses religiously motivated conduct, but the clearest example is chosen to bring this out:

$\mathrm{D}$, a preacher, says that gender reassignment surgery is an abomination in the eyes of God, and compares those who undergo it to the cult eunuchs of pagan religion. This is an argument that certain behaviour is sinful and abhorrent but, without more (for example, a demand that transgender people should be executed), would be protected by the right to freedom of expression (and freedom of religion). ${ }^{9}$

This neglects the bigger picture. Religious critique is one way in which the values of a particular society may be challenged, and perhaps come to be changed, through 'influential, voluntary contributions to debate on matters of profound public controversy'. ${ }^{\circ}$ As Gozdecka puts it, 'Pluralism in its thickest

5 It does not consider incitement to violence or criminal acts more generally, on which see A Buyse, 'Dangerous expressions: the ECHR, violence and free speech', (2014) 63 International and Comparative Law Quarterly 491-503.

$6 \quad R$ (on the application of Hodkin and another) $v$ Registrar General of Births, Deaths and Marriages [2013] UKSC 77 at para 57.

7 Eg I Hare, 'Crosses, crescents and sacred cows: criminalising incitement to religious hatred', (2006) Public Law $521-538$ at 534 .

8 Eg K McGuire and M Salter, 'Legal responses to religious hate crime: identifying critical issues', (2014) 25 Kings Law Journal 159-184.

9 Law Commission, Hate Crime: should the current offences be extended?, report no 348 (London 2014), p 200.

10 Hare, 'Crosses, crescents and sacred cows', p 535. 
form is ... a dynamic force that allows for constant challenges and creates a space for all forms of renegotiation that can slowly transform and shake the status quo." Critique provided by religious communities should be seen as a public good. No human society is perfect, ${ }^{12}$ and some religious traditions see challenging social imperfections as an important contribution that religious individuals and communities can make to their societies. ${ }^{13}$ Religious critique is one way in which the values of a particular society may be challenged, and perhaps come to be changed, through 'influential, voluntary contributions to debate on matters of profound public controversy'. ${ }^{14}$ Accepting critique as a public good is not the same as accepting that it should always be permitted. In particular, critique can have an individualised cost borne by those subject to the critique. Taking proper account of these costs means that it does not always follow that victims 'who detest hate speech should just learn to live with it'. ${ }^{15}$ It does mean, however, that oppositional religious speech has particular value because it is oppositional.

The same perspective sees critique of religious values as a community good. The importance of such critiques has been recognised by, for instance, the European Court of Human Rights in Otto-Preminger Institut v Austria, where the court found that

Those who choose to exercise the freedom to manifest their religion ... cannot reasonably expect to be exempt from all criticism. They must tolerate and accept the denial by others of their religious beliefs and even the propagation by others of doctrines hostile to their faith. ${ }^{16}$

Recognising the value of critique of shared values makes this more than simply a burden to be borne, instead constructing it as a private good to the religious community. Such critique can come from outside a religious community but also from within the community itself. Religious resources can be, and are, used not only as a critique of secular values but also as a critique of the values of co-religionists. I return to this below.

This oppositional religious speech may be based upon religious scripture, which can be central to understanding the beliefs of a community. ${ }^{17}$ It is possible

11 D Gozdecka, Rights, Religious Pluralism and the Recognition of Difference: off the scale of justice (Abingdon, 2016), p 94.

12 My argument here draws on Mill, and in particular concerns about infallibility, and is subject to the criticisms of P Wragg, 'Mill's dead dogma: the value of truth to free speech jurisprudence', (2013) Public Law 363-385.

13 Within many strands of Christianity, for instance, prophets are seen as important challengers to social values: see 2 Chronicles 24:19.

14 Hare, 'Crosses, crescents and sacred cows', 535.

15 J Waldron, The Harm in Hate Speech (Cambridge, MA, 2012), p 3.

16 Otto-Preminger Institut v Austria App no 13470/87 (ECtHR, 20 September 1994) at para 47.

17 Cha'are Shalom ve Tsedek v France App no 27417/95 (ECtHR, 27 June 2000) at paras 13-16. 
to identify a wide range of instances in which religious scripture appears to justify or require hostility towards a protected group, or their practices, in a way which fails to mirror current state policy on equality and nondiscrimination. Particular religious practices are condemned by the Qur'an; ${ }^{18}$ racial discrimination has been justified by reference to the scripture of the Latter-Day Saints, ${ }^{19}$ and despising disabled people has been justified by reference to Hindu scripture. ${ }^{20}$ Turning to the highest-profile contemporary issue, on sexual orientation many Jews and Christians would treat as scripture the passage in Leviticus which states 'Thou shalt not lie down with mankind as with womankind; it is an abomination. ${ }^{21}$

The status of this scripture will vary enormously, even within those communities which see it as an authentic part of their religious worldview. So selfidentifying Christians will give varying weight to, for instance, the Old Testament, the New Testament, the teachings of the Catholic Church, the prophetic insights of the President of the Church of Jesus Christ of the Latter-Day Saints and the conscience of the individual. Similarly, the origins of scripture will vary enormously across different religions. The largest world religions have significant bodies of scripture which were generated in the distant past, but others have created their bodies of scripture within living memory. Particularly in the case of the older bodies of scripture, however, interpretation of them has been a substantial intellectual project, in some cases one that has taken place over millennia. This project will, on occasions, generate an understanding of the body of scripture which may differ considerably from that of an outsider exposed to the bare words of the text for the first time. ${ }^{22}$

These factors run counter to a monolithic view of particular religious people, religions or families of religions. The examples above are intended to illustrate the resources available to those within or without the community which, on a bare reading of the text, may be apt to show that the religion is hateful. It should be stressed, however, that these examples should not be taken as indicating that every person who self-identifies as a member of the religious group in question would condemn in the terms outlined. There are, for instance, selfidentifying Christians who do not see any distinction between homosexual and heterosexual relationships, including but not limited to LGBT Christians $;^{23}$ and there are Jews who do not regard witchcraft as contrary to

23 See further P Edge, 'Let's talk about a divorce: religious and legal wedding' in J Miles, P Mody and R Probert (eds), Marriage Rites and Rights (Oxford and Portland, OR, 2015), pp 255-274. 
their religion, including Jewitches who identify as both Jews and witches. ${ }^{24}$ Nonetheless, it is clear that there is real potential for preaching of scriptures revered by significant communities in the UK to constitute condemnation of groups, and practices by members of those groups, protected by comparative recent developments in equality law. One thread of equality law is the protection of groups sharing a protected characteristic from hate speech and hate crime. The next section considers the development of this area of law.

\section{INTRODUCING HATE SPEECH AND HATE CRIME COMMITTED BY SPEECH}

Hatred law in England and Wales has two main branches: hate crime and hate speech. A hate crime is a crime aggravated by the existence of a proscribed type of hostility. Some crimes can be committed by speech alone, and in those cases the speech crime may constitute a hate crime. Thus hate crime blurs easily into hate speech. The distinctive feature of hate speech is communication apt to create hatred in the minds of others in relation to a prohibited ground. In purely numerical terms, prosecutions and convictions for hate speech offences are very much less common than hate crimes. ${ }^{25}$

Before 2001 only hostility on the grounds of race could form the basis of a hate crime. The Crime and Disorder Act 1998 (hereafter CDA 1998) took two distinct routes to increase the punishment of racial hate crime. ${ }^{26}$ It created substantive hate crimes, which required racial aggravation of a particular basic offence and carried substantially higher maximum sentences. The basic offences included public order offences involving harassment, alarm, distress, fear or provocation of violence, ${ }^{27}$ as well as the statutory offences defined under the Protection from Harassment Act $1997 .{ }^{28}$ This part of the Act was focused on offending previously identified by the judiciary as meriting extra punishment if racially motivated. ${ }^{29}$ For almost all other offences, the legislation provided that racial aggravation was to be treated as a factor increasing the seriousness of the offence, ${ }^{30}$ with no change to the maximum penalty. ${ }^{31}$ The racial hatred provisions were intended to apply to ethno-religions such as Judaism, ${ }^{32}$ but not to religions such as Islam, categorised as 'a poly-ethnic religious

M Raphael, 'Goddess religion, postmodern Jewish feminism and the complexity of alternative religious identities', (1998) 1:2 Nova Religio 198-215.

25 Law Commission, Hate Crime, para 7.70.

26 Repeated by the Powers of Criminal Courts (Sentencing) Act 2000, s 153; Criminal Justice Act, s 145.

27 CDA 1998, s 31.

28 CDA $1998, \mathrm{~s} 32$.

29 See P Edge, 'Extending hate crime to religion', (2003) 8 Journal of Civil Liberties 5-27.

30 CDA 1998, s 82(1).

31 Law Commission, Hate Crime, consistently treats this as the most significant difference between the two routes, for instance at paras 4.114-4.130.

32 Alun Michael MP, HC Deb 8 April 1998, vol 310, col 451. 
community and not a racial group'. ${ }^{33}$ The concept of hate crime has been expanded into grounds other than race: religion in $2001,{ }^{34}$ sexual orientation and disability in $2003^{35}$ and transgender identity in 2012. ${ }^{36}$ Only for religion was the distinction between aggravated offences and sentence enhancement retained, despite arguments for parity across the different grounds. ${ }^{37}$

Turning to hate speech, again the crime was initially restricted to racial hatred. The key modern legislation, ${ }^{38}$ the Public Order Act 1986 (hereafter POA 1986), created a number of offences, of which the most significant is the use of threatening, abusive or insulting words or behaviour which is either intended to stir up racial hatred or is likely to stir up racial hatred. ${ }^{39}$ This incitement offence requires that the defendant intended to stir up racial hatred, or was reckless as to whether this was the result. Also significant to later discussion is the offence of possessing written material or audio-visual recordings which are threatening, which the person holds with a view to distribution or publication, and which the person intends to use to stir up hatred. ${ }^{40}$ Such materials may be seized and forfeited..$^{41}$ The original provisions did not cover religion, but were extended to religion in 2006 and to sexual orientation in $2008 .{ }^{42}$

The Racial and Religious Hatred Act 2006 added a new Part IIIA to the 1986 Act, which includes both the use of threatening or abusive words and behaviour which are intended to stir up religious hatred, ${ }^{43}$ and a range of ancillary offences. ${ }^{44}$ Incitement to religious hatred represents 'a considerable dilution of earlier and parallel incitement to "racial hatred" laws'. ${ }^{45}$ Incitement to racial hatred can be committed by merely insulting or abusive words or behaviour, while incitement to religious hatred cannot. Incitement to racial hatred can be committed intentionally or recklessly, while incitement to religious hatred can only be committed intentionally. Additionally, the religious incitement provision has a special saving clause in section 29J, which provides that nothing in Part IIIA prohibits or restricts

33 Iganski, Sweiry and Culpeper, 'Question of faith', p 334.

34 See A Roulstone, P Thomas and S Balderston, 'Between hate and vulnerability: unpacking the British Criminal Justice System's construction of disablist hate crime', (2011) 26:3 Disability and Society 351.

35 Criminal Justice Act 2003, s 146.

36 Legal Aid, Sentencing and Punishment of Offenders Act 2012, s 65.

37 See C Heard, 'Hate crime law: more incrementalism or time for reform?' (2014) 7 Archbold Review 4-5.

38 For antecedents, see P Leopold, 'Incitement to hatred: the history of a controversial criminal offence', 1977 Public Law 389-405; Hare, 'Crosses, crescents and sacred cows'.

39 POA 1986, s 18. Part 3 also contains prohibitions on publishing material, possessing material, performance of plays, distributing and showing recordings, and broadcasting.

40 POA 1986, s $29 \mathrm{G}$.

41 Ibid, s 29H-I.

42 Criminal Justice and Immigration Act 2008, s 74.

43 POA 1986, s 29B.

44 Ibid, $\mathrm{s} 29 \mathrm{C}-\mathrm{G}$.

45 McGuire and Salter, 'Legal responses', p 163. 
discussion, criticism or expressions of antipathy, dislike, ridicule, insult or abuse of particular religions or the beliefs or practices of their adherents, or of any other belief system or the beliefs or practices of its adherents, or proselytising or urging adherents of a different religion or belief system to cease practising their religion or belief system.

\section{OPPOSITIONAL RELIGIOUS SPEECH, SCRIPTURAL CITATION AND HATE LAW}

Applying hate law to oppositional religious speech based upon scriptural citation brings out potential problems, some of which may be capable of being resolved by particular interpretations of the current law, while others are not.

\section{Criminal prosecution for citation of scripture}

In Kirk Session of Sandown Free Presbyterian Church, the Kirk Session had placed a newspaper advert condemning homosexual acts, making use of biblical quotations. ${ }^{46}$ The Advertising Standards Authority initially upheld complaints that the advert was homophobic and had caused serious offence. The independent reviewer noted that the advert used 'selective quotations from the Bible', noting particularly the omission of the call for execution in Leviticus 20:13. He also thought that 'it was reasonable for the Council to consider that codes of conduct and sanctions laid down in biblical works from several millennia ago cannot be communicated verbatim and indiscriminately in twenty first century advertising'. The Kirk Session was thus criticised for both selectivity and lack of discrimination. The Kirk Session appealed, the key issue being whether the restriction was proportionate.

The judge noted that the 'essence' of the applicant's religious beliefs was based on scripture: 'One effect of the impugned decision is to materially interfere with and inhibit their use of certain biblical scripture. ${ }^{\prime 7}$ The judge found that the restriction was disproportionate, in part because the advertisement 'constituted a genuine attempt to stand up for their religious beliefs and to encourage others to similarly bear witness and did so by citing well known portions of scripture which underpinned their religious faith and their call to witness'. ${ }^{4}$ The court in Kirk Session treated the use of scriptural quotations as criticism as significantly different even from religiously motivated criticism simpliciter. How would this scenario be dealt with by hate law? 
The provisions regarding the stirring up of hatred would not apply. The provisions on stirring up hatred on the grounds of sexual orientation have demanding mens rea and actus reus requirements. ${ }^{49}$ Reinforcing this view is the specific statutory provision which states that 'for the avoidance of doubt, the discussion or criticism of sexual conduct or the urging of persons to refrain from or to modify such conduct or practices shall not be taken of itself to be threatening. ${ }^{\circ}{ }^{\circ}$ The exclusion of this scenario from hate crime is, however, much less obvious. If the citation of the scripture was in circumstances which rendered it a criminal offence, most likely as a public order offence, then the words of the scripture could be read as a demonstration of hostility towards the protected group. Hate crime, in sharp contrast to hate speech, does not require that hostility actually exists (discussed more fully below), nor does it provide the statutory saving for criticism of sexual conduct or practices found in hate speech law.

As well as being cited, scripture has a physical existence. In Kirk Session, the speakers omitted a scriptural call for execution contained in the Bible. Is it a crime to possess a scripture containing such a call? Hate crime has little application here, but hate speech may. For stirring up racial hatred, the law criminalises the possession of written material or audio-visual recordings which are threatening, which the person holds with a view to distribution or publication, and which the person intends to use to stir up hatred..$^{51}$ A similar offence was later added for stirring up religious hatred, ${ }^{52}$ and for stirring up hatred on the grounds of sexual orientation. The later additions are, however, subject to the specific saving clauses (quoted above) which protect criticism of practice. Calls for the death of those who carry out particular sexual practices would seem to go well beyond the type of speech envisaged by the statutory savings, however, and could easily constitute threatening materials: the key issue will then be the mens rea of the person possessing the scripture.

\section{Misconstruing hostility towards a protected characteristic}

A growing concern in the UK is the relative lack of religious literacy in a complex, religiously plural, society. Religious speech may be perceived, when shorn of context, as prohibited hostility when it is not intended in this way at all. A holy symbol of the Raelian Movement is an intertwining of the Star of David with the Swastika. ${ }^{53}$ Although positive and sacred to Raelians, others see it as a tremendously offensive symbol. How would displaying the symbol be treated?

Religious hate speech is unlikely to apply. A Raelian displaying the symbol would be able to argue that the display did not reach the level of threatening 
words and, crucially, that they lacked the intention to stir up religious hated.54 Jewish communities, however, are an example of ethno-religions, where the community is defined simultaneously as an ethnic group and a religion. The law on inciting racial hatred is notably less protective of the speaker than that of religious hatred - in particular, the mens rea requirement is satisfied by recklessness as to stirring up racial hatred; and merely insulting or abusive conduct can constitute the actus reus. ${ }^{55}$ A finder of fact may be prepared to find that in this scenario the defendant was reckless as to stirring up racial hatred against Jewish people, and that the display was insulting to Jewish people.

In relation to hate speech, this scenario is only problematic because of the ethno-religious status of Judaism. The application of hate crime, however, goes wider. Under section 28(1)(a) of the CDA, religious and racial hate crime can be satisfied by a demonstration of hostility even in the absence of actual hostility. ${ }^{56}$ Not all offences can be based upon demonstrating hostility towards the victim of the offence, ${ }^{57}$ but the religiously or racially aggravated public order offences involving harassment, alarm, distress, fear or provocation can. ${ }^{8}$ In these cases, the aggravated penalty would be applicable if the display of the holy symbol was found to demonstrate racial or religious hostility, even if the defence were to prove the absence of any hostile motivation.

\section{Misconstruing the religious element in desacralised symbols and language}

What of scripture which has become unmoored from its religious context and is being used simply as a convenient mode of expressing hostility towards an individual? Hare has suggested that '[all] members of the criminal justice system must ... be very wary of reading alleged statements out of the context in which they were originally articulated. ${ }^{59}$ This is particularly important in relation to language derived from some religious traditions but which has retained a secular meaning that may be divorced entirely from any religious context. The Italian government in Lautsi argued for a desacralised meaning of the crucifix. ${ }^{6 \circ}$ If a crucifix can be desacralised, what of religious language and citation of scripture?

During the passage of the 2001 legislation, the example was given of a footballer abused as 'Judas' because he had changed clubs. ${ }^{61}$ 'Judas' may be a desacralised equivalent to 'betrayer'. If there is no recognition of the desacralisation of prima facie religious language, the scope of demonstration may be considerably expanded. In that case it may not be enough to find that the defendant was not consciously 
aware of the religious connotations of the term, as cases on racial epithets have suggested that this is irrelevant in determining their liability under demonstration.

\section{State involvement in intra-communal disputes}

Oppositional religious speech can be a communal good generated by disputes within a religious community. ${ }^{62}$ Additionally, there is a strong theme in court decisions on the importance of the autonomy of religious organisations, which suggests that the state should be particularly cautious to intervene in a doctrinal dispute within a religious community. The courts have found that hostility towards an individual on the basis of their membership of a group can occur even where the defendant is also a member of that group. ${ }^{63}$ One positive feature of this approach is that complex issues of religious identity - for instance, whether Protestants and Catholics share a religion ${ }^{64}$ - do not need to be resolved in order to apply hate law to a scenario.

The inclusion of intra-group interaction may fairly be seen as a recognition of the ongoing, intimate, nature of some hate crime offending. ${ }^{65}$ In relation to intra-religious conflict, however, it could lead to the state punishing conflict within a religious group more seriously than other conflict. In this scenario, the state is not acting to protect members of the group from outsiders, but instead from one another. This raises significant issues concerning the autonomy of religious communities to determine their internal values and structures free from state control.

\section{WAYS FORWARD?}

The previous sections raised concerns around two important elements of religious liberty: the right to manifest religious belief, and the right to autonomy of religious organisations and communities. We should consider ways to minimise the burden on the religious preacher and their community while giving proper weight to the importance of hate law. An emphasis on religious rights can justify departing from balances of proportionality struck for freedom of expression alone, and directs attention to specific features of the preaching moment which are relevant to proportionality. There are five features that a court should be mindful of in this proportionality exercise.

First, the significance of the exercise of religious rights by the preacher needs to be recognised. The general cases on mixed motives, ${ }^{66}$ would suggest that an

63 White [2001] EWCA Crim 216, 1 WLR 1352, CA. Cf Pal [2000] Crim LR 756.

64 D Abrams, H Swift and L Mahmood, Prejudice and Unlawful Behaviour: exploring levers for change, EHRC Research Report 101 (2016), p 78.

65 See, for instance, M Walters, "Why the Rochdale Gang should have been sentenced as "hate crime" offenders', (2013) Crim LR 131-144 at 139.

66 Eg Mihocic [2012] EWCA Crim 195 (CA). 
intention to manifest religion is irrelevant if it can be shown that there is any element of the prohibited mental element or, for hate crime, a demonstration of hostility even in the absence of actual hostility. To give proper weight to freedom of religion, however, the courts should be prepared to depart from this and to accept that the required hostility or intent to stir up hatred can be entirely displaced by the intention to manifest religion; and that what is prime facie a demonstration of hostility can best be understood as a manifestation of religion. The context in which a statement is made - which can include, for instance, being 'the wider context and circumstance of him delivering a sermon wherein he was trying to communicate strong and robust beliefs that the God in which he believed was the only true God and that the worship of any other god was idolatrous ${ }^{, 67}-$ is crucial to understanding whether hate law applies. In particular, the courts need to be sensitive to the context when deciding whether a particular manifestation of religion constitutes a demonstration of hostility under hate crime law. Sensitivity is also needed around desacralised language.

Second, one of the specific concerns raised above was the application of hate law to internal conflicts and debates within a religious community. If, as I have suggested, it is possible to understand a transaction as turning not on prohibited hostility but on an intent to manifest religion or belief, it is at least as easy to understand intra-group hostility as based on personal animus, or personal conduct, to the exclusion of the shared group identity. Emphasising, once again, the distinctive place of freedom of religion, it would be possible for the courts to depart from this line and to favour an approach where, for intra-religious offending, the natural finding of fact in most cases would be to exclude the transaction from the reach of hate law.

Third, some religious people who use biblical texts to condemn same-sex activity distinguish strongly between condemning a person and condemning their actions. One way of putting this is to talk of hating sin but loving sinners. It may be easier to justify the condemned sharing the cost of condemnation when it is possible for them to respond to the condemnation. This is not necessarily because they are to be held at fault, so that they have a duty to change. Rather, it is because the public good of being condemned is something which it is comparatively easy for them to take advantage of. A smoker who is convinced by the condemnation that they are at fault can take advantage of this by ceasing to be a smoker. It is notably less easy for a person who becomes convinced that they should not be a man, or that they are homosexually orientated, to take advantage of a condemnation of either of those characteristics. This absence of a benefit to the target of the criticism should be taken into account in gauging proportionality. 
Fourth, the court should not take account of the religious methodology of a user of scripture. It is tempting to treat scriptural citation as an exercise of scientific judgement. Taking this approach, a speaker who makes fair use of their sources may be able to rely upon their reporting of these sources, while one who distorts the sources by unfair use may not. This approach would entangle the state in determining the true reading, or range of true readings, of religious texts - a function it is not well placed to carry out.

Finally, the court needs to be aware that the citation of scripture is a contemporary moment, regardless of the antiquity of the source used. The court needs to keep a focus on the actions and motivation of the human being making use of the sources and may find it useful to consider the extent to which the speaker owns the scripture. This focus on ownership has an important implication for the discussion on materials given above. An individual must take ownership of the condemnatory words to be held to account for them. In the examples given above, the particularly condemnatory words form part of a considerable corpus of sacred texts. An individual may distribute this corpus without necessarily owning every part of it, even if in principle they would assert that they do. This emphasis on ownership would not be a complete innovation in religious hate law: for the offence of presenting a play intended to stir up religious hatred, an actor is only liable if they make the hateful performance their own by ignoring direction. ${ }^{68}$

Even if the courts were prepared to take the principles outlined in this section and apply them as fully as possible to preachers faced with prosecutions under hate law, the current statutory framework is itself problematic. Offences of stirring up hatred have particular protection for oppositional speech, in relation to the specific saving clauses for religion and sexual orientation. There is an argument, made particularly pressing by the position of the ethno-religions, for considering whether inciting hatred against racial practices should have similar savings to those for religious and sexual orientation practices. There is also an argument for considering whether speech which would fall within a saving clause in relation to hate speech should be excluded from the context which may be used to find a hate crime. Such reforms are likely to be very contentious, particularly if they are understood as protecting oppositional religious speech against the application of state values. The key point here is that the conflict between oppositional religious speech and state values is only on the surface. Recognition of the special status of religion or belief in the life of our fellow citizens, and accommodation - in appropriate circumstances - of their religious interests, is a fundamental state value in the UK. 